\title{
Evaluating the Relative Efficiency of Commercial Banks in Turkey: An Integrated AHP/DEA Approach
}

\author{
Ilker Murat $\mathrm{Ar}^{1} \&$ Ahmet Kurtaran ${ }^{1}$ \\ ${ }^{1}$ Department of Business Administration, Karadeniz Technical University, Trabzon, Turkey \\ Correspondence: Ahmet Kurtaran, Department of Business Administration, Karadeniz Technical University, \\ Trabzon, Turkey. Tel: 90-462-377-8779. E-mail: kurtaran@ktu.edu.tr
}

Received: January 29, 2013

Accepted: March 1, $2013 \quad$ Online Published: March 11, 2013

doi:10.5539/ibr.v6n4p129

URL: http://dx.doi.org/10.5539/ibr.v6n4p129

\begin{abstract}
This study measures the relative efficiency of 13 commercial banks in Turkey for the year of 2011 with an integrated approach includes Analytic Hierarchy Process and Data Envelopment Analysis. It uses two inputs (personnel expenditures and number of branch) and four outputs (deposits-national currency, deposits-foreign currency and precious metal, cash loans, and non-cash loans) in terms of production approach. According to empirical result, state-owned commercial banks are efficient in both CCR (Charnes-Cooper-Rhodes) and BCC (Banker-Charnes-Cooper) model. However, foreign-owned commercial banks have the lower efficiency scores than both state-owned and private-owned commercial banks. The results also suggest that inefficient banks should especially improve their non-cash loans and should focus on their annual personnel expenditure. Moreover, more than half of the commercial banks are scale inefficiency. The results of the study may be useful for the bank managers in assessing their performance.
\end{abstract}

Keywords: efficiency analysis, data envelopment analysis, analytic hierarchy process, weight restrictions, commercial banks, Turkey

\section{Introduction}

Banking sector in transition and developing economies has experienced major transformations since the 1990s. Over the last few decades, the banking sectors around the world have experienced financial globalization, technological changes, and competition. Banks are also faced with increasing competition and rising costs as a result of regulatory requirements, financial and technological innovation, and challenges of the recent financial crisis. Moreover, banking sector has changed with the advanced applications in computer and communications technology and introduction of new financial instruments. Such changes have significantly modified bank production. In this regard, a frequently asked question is about the effect of these changes on the efficiency of banks (Grigorian \& Manole, 2002). So, efficiency analysis of banks has received increasing attention from researchers in recent years. It has also become important to assess the relative role of different institutional and policy settings in explaining the difference between banks (Grigorian \& Manole, 2002).

Due to the increased competition in developed countries, financial institutions look for expanding their market shares in developing countries as Turkey. The banking system in Turkey is the most common instrument in exercising economic and monetary policy. Thus, efficiency analysis of the banks is the key issue in the Turkish managers' agenda. Also, efficiency measurement of the banks has an important role in the efficiency of Turkish financial system. It is not surprising that the banking sector and its efficiency is one of the most popular issues in Turkey.

Turkey has a notably $(8.5 \%)$ economic growth while average economic growth rate of the world is $3.9 \%$ in 2011 (The Banks Association of Turkey, 2012). Therefore, Turkish banking sector has been taken attention all over the world. According to data from The Banks Association of Turkey (2012), Figure 1 presents proportion of size Turkish banking sector to Gross Domestic Product (GDP) by years. As shown the Figure 1, proportion of total assets, loans and deposits to GDP invariably in last seven years exception for decrease deposit rate in 2011. Especially it can be said that increase of asset/GDP with $90 \%$ is most remarkable growing. Consequently, Turkish banking sector has grown as far as GDP upward. 


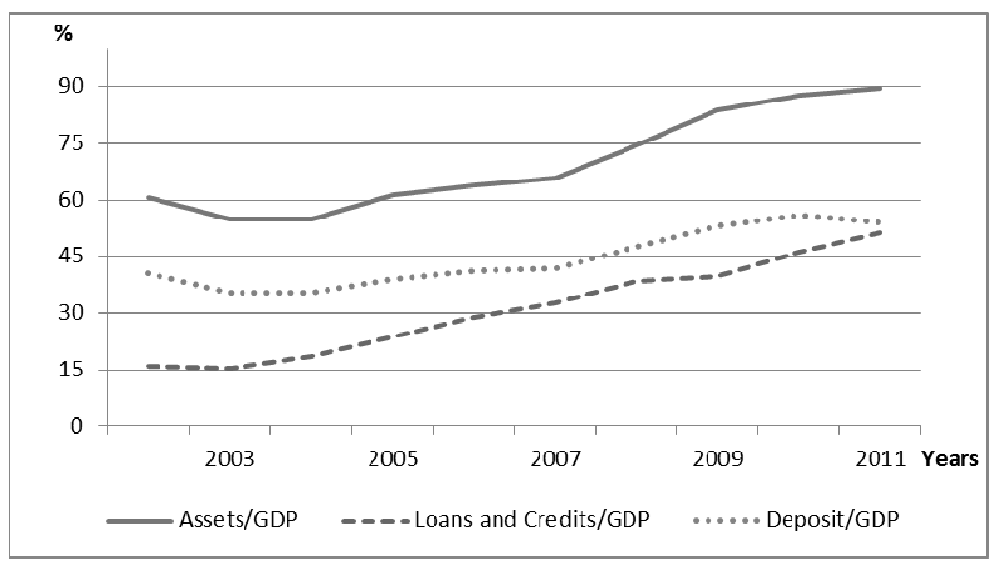

Figure 1. Turkish banking sector (2002-2011)

Turkish banking system constitutes three functional banking groups such as commercial banks, participation banks, and development and investment banks. The number of these banks is 31, 4 and 13 respectively (Banking Regulation and Supervision Agency, 2011). According to statistics from Banking Regulation and Supervision Agency (2011), they reached the total assets of 1217.7 billion TRY by the year of 2011. Thus, commercial banks have an important role in Turkish banking system. According to Yue (1992), commercial banks have a vital role in the economies for two reasons. Firstly, they provide a major source of financial intermediation. Secondly, their checkable deposit liabilities represent the bulk of the nation's money stock. Measuring and evaluating their overall performance and monitoring their financial condition is important to depositors, owners, potential investors, managers and, of course, regulators (Yue, 1992).

Data Envelopment Analysis (DEA), which is a mathematical programming approach, has become the most commonly used non-parametric approach to estimating the efficient frontier. DEA clearly brings out the firms that are operating more efficiently in comparison to other firms in the industry. Moreover, it points out the areas in which poorly performing firms need to improve (Malhotra et al., 2009). So, it is also the most widely used methods in order to measure the relative efficiency of financial institutions. In the banking sector, DEA approach allows us to measure an individual bank performance by measuring its efficiency compared to the peer group banks. This study has combined the Analytic Hierarchy Process (AHP) which is a popular tool in the field of multiple criteria decision making and DEA to create a suitable performance evaluation model.

This study aims to measure the relative efficiency of commercial banks in Turkey by DEA. It is organized as follows: Section 2 gives a brief review of the relevant literature and specifically variables used as inputs and outputs in similar studies. Section 3 gives a theoretical background on the research methods. Section 4 describes the model used in this study and introduces the data. Results are given in section 5. Finally, section 6 concludes the study.

\section{Literature Review}

Effective working of banking sector has a substantial position on development of financial markets. So, there are a lot of studies on efficiency of banks in the literature. There are two measurement techniques as parametric and non-parametric methods for efficiency measurement of banks in the literature. Financial ratio analysis, regression analysis, and stochastic frontier analysis are general parametric methods. These parametric approaches specify a functional form for the cost, profit, or production relationship among inputs, outputs and environmental factors, and allow for random error (AlKhathlan \& Malik, 2010).

Non-parametric techniques do not require the specification of an a priori functional form and therefore is the most favored approach (AlKhathlan \& Malik, 2010). DEA, as a non-parametric technique, is one of the most popular tools for performance measurement. It determines the productive efficiency of a system or decision-making-unit (DMU) by comparing how well the DMU converts inputs into outputs. DEA is also the most commonly used non-parametric technique in the banking sector. Barr et al. (2002) indicated that DEA is a reliable tool for determining banks operation efficiencies.

There are numerous applications of DEA in the bank performance literature. For example many scholars (Vassiloglou \& Giokas, 1990; Al-Faraj et al., 1993; Sherman \& Ladino, 1995; Athanassopoulos, 1997; Lovell \& Pastor, 1997; Golany \& Storbeck, 1999; Dekker \& Post, 2001; Porembski et al., 2005; Mansoury \& Salehi, 
2011) evaluated the branch efficiency. They focused on branches of the only one bank.

DEA was also used to measure the bank efficiency for various countries by many researchers (Berg et al., 1993; Altunbas \& Molyneux, 1996; Allen \& Rai, 1996; Pastor et al., 1997; Kuosmanen \& Post, 2001; Grigorian \& Manole, 2002; Maudos et al., 2002; Maea, 2010). They aimed to present the effects of country's regulatory environments on bank efficiency.

This study focuses on the efficiency measurement of commercial banks in Turkey. So, its literature review was restricted with studies using DEA models for efficiency measurement of commercial banks. As a conclusion, much information about selected studies is given in Table 1.

Table 1. Selected studies focus on the efficiency measurement of commercial banks

\begin{tabular}{|c|c|c|c|c|}
\hline Study & Sample & Inputs & Outputs & Model \\
\hline Yue (1992) & $\begin{array}{l}60 \text { Missouri (USA) } \\
\text { commercial banks }\end{array}$ & $\begin{array}{l}\text {-Interest expenses } \\
\text {-Non-interest expenses } \\
\text {-Transaction deposits } \\
\text {-Non-transaction deposits }\end{array}$ & $\begin{array}{l}\text {-Interest income } \\
\text {-Non-interest income } \\
\text {-Total loans }\end{array}$ & CCR \\
\hline $\begin{array}{l}\text { Taylor et al. } \\
\text { (1997) }\end{array}$ & $\begin{array}{l}13 \quad \text { Mexican } \\
\text { commercial banks }\end{array}$ & $\begin{array}{l}\text {-Total deposits } \\
\text {-Non-interest expense }\end{array}$ & $\begin{array}{l}\text {-Total income (interest income plus } \\
\text { non-interest income) }\end{array}$ & $\begin{array}{l}\text { CCR and } \\
\text { BCC-Input } \\
\text { oriented }\end{array}$ \\
\hline $\begin{array}{l}\text { Al-Shammari } \\
\text { and Salimi } \\
(1998)\end{array}$ & $\begin{array}{l}16 \quad \text { Jordan } \\
\text { commercial banks }\end{array}$ & No inputs were specified & $\begin{array}{l}\text {-Return on investment } \\
\text {-Return on equity } \\
\text {-Earnings per share } \\
\text {-Credits to total assets } \\
\text {-Credits to deposits } \\
\text {-Cash and portfolio investment to deposits }\end{array}$ & $\begin{array}{l}\text { DEA - Ratio } \\
\text { model }\end{array}$ \\
\hline Avkiran (1999) & $\begin{array}{l}23 \text { Australian } \\
\text { trading banks }\end{array}$ & $\begin{array}{l}\text { Model } A \\
\text {-Interest expense } \\
\text {-Non-interest expense } \\
\text { Model B } \\
\text {-Net-interest income } \\
\text {-Non-interest income }\end{array}$ & $\begin{array}{l}\text {-Deposits } \\
\text {-Staff numbers } \\
\text {-Net loans } \\
\text {-Non-interest income }\end{array}$ & DEA \\
\hline $\begin{array}{l}\text { Saha and } \\
\text { Ravisankar } \\
(2000)\end{array}$ & $\begin{array}{l}25 \quad \text { Indian } \\
\text { commercial banks }\end{array}$ & $\begin{array}{l}\text {-Number of branches } \\
\text {-Number of employees } \\
\text {-Establishment expenditure } \\
\text {-Non-establishment expenditure }\end{array}$ & $\begin{array}{l}\text {-Deposits } \\
\text {-Advances } \\
\text {-Investments } \\
\text {-Spread } \\
\text {-Total income } \\
\text {-Interest income } \\
\text {-Non-interest income } \\
\text {-Working funds }\end{array}$ & $\begin{array}{l}\text { CCR-Input } \\
\text { oriented } \\
\text { model }\end{array}$ \\
\hline $\begin{array}{l}\text { Barr et al. } \\
(2002)\end{array}$ & $\begin{array}{l}50 \text { US commercial } \\
\text { banks }\end{array}$ & $\begin{array}{l}\text {-Laboring costs } \\
\text {-Fixed assets } \\
\text {-Interest and Non-interest costs } \\
\text {-Deposits }\end{array}$ & $\begin{array}{l}\text {-Revenues } \\
\text {-Interest incomes } \\
\text {-Non-interest incomes }\end{array}$ & $\begin{array}{l}\text { CCR-Input } \\
\text { oriented }\end{array}$ \\
\hline Sathye (2003) & $\begin{array}{l}94 \quad \text { Indian } \\
\text { commercial banks }\end{array}$ & $\begin{array}{l}\text { Model } A \\
\text {-Interest expenses } \\
\text {-Non-interest expenses } \\
\text { Model B } \\
\text {-Deposits } \\
\text {-Staff numbers }\end{array}$ & $\begin{array}{l}\text {-Net interest income } \\
\text {-Non-interest income } \\
\text {-Net loans } \\
\text {-Non-interest income }\end{array}$ & $\begin{array}{l}\text { BCC- Input } \\
\text { oriented }\end{array}$ \\
\hline $\begin{array}{l}\text { Halkos and } \\
\text { Salamouris } \\
(2004)\end{array}$ & $\begin{array}{l}15,17, \text { and } 19 \\
\text { Greek commercial } \\
\text { banks for each }\end{array}$ & No inputs were specified & $\begin{array}{l}\text {-Return difference of interest bearing } \\
\text { assets } \\
\text {-Return on equity } \\
\text {-Return on total assets } \\
\text {-Efficiency ratio } \\
\text {-Net interest margin }\end{array}$ & $\begin{array}{lr}\text { CCR } & \text { and } \\
\text { BCC- } & \text { Ratio } \\
\text { model } & \end{array}$ \\
\hline $\begin{array}{l}\text { Portela and } \\
\text { Thanassoulis } \\
(2005)\end{array}$ & $\begin{array}{l}60 \quad \text { Portuguese } \\
\text { bank branches }\end{array}$ & $\begin{array}{l}\text {-Number of staff } \\
\text {-Value current accounts }\end{array}$ & $\begin{array}{l}\text {-Supply costs } \\
\text {-Value other resources } \\
\text {-Value credit by bank } \\
\text {-Value credit associates }\end{array}$ & $\begin{array}{l}\text { BCC-Input } \\
\text { oriented }\end{array}$ \\
\hline
\end{tabular}




\begin{tabular}{|c|c|c|c|c|}
\hline $\mathrm{Li}(2006)$ & $\begin{array}{l}14 \quad \text { Chinese } \\
\text { commercial } \\
\text { banks }\end{array}$ & $\begin{array}{l}\text {-Employees } \\
\text {-Capital } \\
\text {-Operating charge rate }\end{array}$ & $\begin{array}{l}\text {-Profit } \\
\text {-Rate/person } \\
\text {-Income rate of assets } \\
\text {-Returning rate of capital } \\
\text {-Trading volume by cards/person }\end{array}$ & CCR \\
\hline $\begin{array}{l}\text { Chen-guo et al. } \\
\text { (2007) }\end{array}$ & $\begin{array}{l}14 \text { Chinese } \\
\text { commercial banks }\end{array}$ & $\begin{array}{l}\text {-The average number of workers } \\
\text {-Net amount of fixed capital } \\
\text {-The total amount of costs (cost of } \\
\text { interest) }\end{array}$ & $\begin{array}{l}\text {-Total amount of deposit } \\
\text {-Total amount of loan } \\
\text {-Total amount of profit before paying tax }\end{array}$ & $\mathrm{BCC}$ \\
\hline $\begin{array}{l}\text { Navabakhsh } \\
\text { et al. (2007) }\end{array}$ & $\begin{array}{l}20 \quad \text { Iranian } \\
\text { commercial banks }\end{array}$ & $\begin{array}{l}\text {-Payable interest } \\
\text {-Personnel } \\
\text {-Non-performing loans } \\
\text {-Number of branch }\end{array}$ & $\begin{array}{l}\text {-Main deposits } \\
\text {-Other deposits } \\
\text {-Loans granted } \\
\text {-Received interest } \\
\text {-Fee }\end{array}$ & $\begin{array}{l}\text { CCR-Input } \\
\text { and Output } \\
\text { oriented }\end{array}$ \\
\hline $\begin{array}{l}\text { Chansarn } \\
(2008)\end{array}$ & $\begin{array}{l}13 \\
\text { commercial } \\
\text { banks }\end{array}$ & $\begin{array}{l}\text { Operational Approach } \\
\text {-Interest expenses } \\
\text {-Labor related expenses } \\
\text {-Capital related expenses } \\
\text { Intermediation Approach } \\
\text {-Total deposits } \\
\text {-Total expense }\end{array}$ & $\begin{array}{l}\text {-Interest and dividend incomes } \\
\text {-Non-interest incomes }\end{array}$ & CCR \\
\hline $\begin{array}{l}\text { Weiguo and } \\
\text { Ming (2008) }\end{array}$ & $\begin{array}{l}5 \text { American and } 4 \\
\text { Chinese } \\
\text { commercialbanks }\end{array}$ & $\begin{array}{l}\text { American Banks } \\
\text {-Operational expense } \\
\text {-Total deposit } \\
\text {-Provision for bad debt } \\
\text { Chinese Banks } \\
\text {-Work force } \\
\text {-Physical assets } \\
\text {-Loanable funds }\end{array}$ & $\begin{array}{l}\text {-Net profit } \\
\text {-Total loan } \\
\text {-Interest income } \\
\text {-Non-interest income }\end{array}$ & $\begin{array}{l}\mathrm{CCR} \\
\mathrm{BCC}\end{array}$ \\
\hline $\begin{array}{l}\text { Subramanyam } \\
\text { and Reddy } \\
(2008)\end{array}$ & $\begin{array}{l}63 \quad \text { Indian } \\
\text { commercial banks }\end{array}$ & $\begin{array}{l}\text {-Number of employees } \\
\text {-Fixed assets }\end{array}$ & $\begin{array}{l}\text {-Deposits } \\
\text {-Loans and advances } \\
\text {-Investments } \\
\text {-Non-interest income }\end{array}$ & $\mathrm{CCR}$ \\
\hline $\begin{array}{l}\text { Moffat and } \\
\text { Valadkhani } \\
\text { (2009) }\end{array}$ & $\begin{array}{l}10 \text { major banks in } \\
\text { Botswana }\end{array}$ & $\begin{array}{l}\text { Value-added approach } \\
\text {-Labour (salaries) } \\
\text {-Capital related operating expenses } \\
\text {-Interest expenses } \\
\text { Intermediation approach } \\
\text {-Deposits } \\
\text {-Labour (salaries) } \\
\text {-Capital related operating expenses } \\
\text { Operating approach } \\
\text {-Interest expenses } \\
\text {-Labour (salaries) } \\
\text {-Capital related operating expenses }\end{array}$ & $\begin{array}{l}\text {-Loans } \\
\text {-Investment } \\
\text {-Deposits } \\
\text {-Loans } \\
\text {-Investment }\end{array}$ & $\begin{array}{l}\mathrm{CCR} \\
\mathrm{BCC}\end{array}$ \\
\hline $\begin{array}{l}\text { Tahir et al. } \\
(2009)\end{array}$ & $\begin{array}{l}22 \text { Malaysian } \\
\text { commercial banks }\end{array}$ & $\begin{array}{l}\text {-Total deposits } \\
\text {-Total overhead expenses }\end{array}$ & -Total earning assets & $\begin{array}{l}\text { BCC-Input } \\
\text { oriented }\end{array}$ \\
\hline $\begin{array}{l}\text { AlKhathlan and } \\
\text { Malik (2010) }\end{array}$ & $\begin{array}{l}10 \text { Saudi Arabian } \\
\text { commercialbanks }\end{array}$ & $\begin{array}{l}\text {-Operating expenses } \\
\text {-Equity capital } \\
\text {-Deposits }\end{array}$ & -Loans and advances (net) & $\begin{array}{l}\text { CCR and } \\
\text { BCC- Input } \\
\text { oriented }\end{array}$ \\
\hline $\begin{array}{l}\text { Akhtar et al. } \\
\text { (2011) }\end{array}$ & $\begin{array}{l}12 \text { commercial } \\
\text { banks in Pakistan }\end{array}$ & $\begin{array}{l}\text {-Operating expense } \\
\text {-Advances } \\
\text {-Capital }\end{array}$ & $\begin{array}{l}\text {-Operating income } \\
\text {-Net-interest income }\end{array}$ & $\begin{array}{l}\text { CCR andBCC } \\
-\quad \text { Input } \\
\text { oriented }\end{array}$ \\
\hline $\begin{array}{l}\text { Varias and } \\
\text { Sofianopoulou } \\
(2012)\end{array}$ & $\begin{array}{l}19 \text { biggest Greek } \\
\text { commercial banks }\end{array}$ & $\begin{array}{l}\text {-Interest expenses/deposits } \\
\text {-Other overhead expenses/fixed assets } \\
\text {-Personnel expenses/total assets }\end{array}$ & $\begin{array}{l}\text {-Loans } \\
\text {-Other earning assets } \\
\text {-Deposits }\end{array}$ & $\begin{array}{l}\text { BCC-Input } \\
\text { oriented }\end{array}$ \\
\hline Ji et al. (2012) & $\begin{array}{l}17 \quad \text { Chinese } \\
\text { commercial banks }\end{array}$ & $\begin{array}{l}\text {-Number of employees } \\
\text {-Interest expense } \\
\text {-Non-interest expenses } \\
\text {-Total assets }\end{array}$ & $\begin{array}{l}\text {-Non-interest income } \\
\text {-Interest income } \\
\text {-Non-performing loan ratio }\end{array}$ & $\begin{array}{l}\text { CCR-Input } \\
\text { Oriented }\end{array}$ \\
\hline
\end{tabular}




\begin{tabular}{llll}
\hline Rao and Lakew 8 and 12 Ethiopian & -Total expenditures on employees & -Total customer loans less provision for \\
$\begin{array}{llll}\text { (2012) } \\
\text { commercialbanks }\end{array}$ & $\begin{array}{l}\text {-Book value of physical capital and } \\
\text { premises }\end{array}$ & -Loubtful & -Total customer deposits \\
\hline
\end{tabular}

There are a number of studies about commercial banks in Turkey. Denizer et al. (2000) employed the DEA to estimate the relative efficiency of 49 commercial banks in Turkey for each year from 1970 to 1994. Jackson and Fethi (2000) investigate the performance of Turkish commercial banking sector. Isik and Hassan (2002) investigated input and output efficiency in the Turkish banking industry to understand the impact of various measures. They also estimated the efficiency of Turkish banks over the 1988-1996 periods. Yunten and Caner (2004) investigated the relative efficiencies of 19 Turkish commercial banks that have been operated between 1999 and 2002.Ozkan-Gunay and Tektas (2006) determined the relative technical efficiency of non-public commercial banks in Turkey between 1990 and 2001 by DEA model. Percin and Ayan (2006) evaluated the efficiency of 31 commercial banks in Turkey using DEA and Malmquist Productivity Index methodologies for the year 2003 and 2004. Ayranci (2011) analyzed the private Turkish commercial banking sector (48 banks) with DEA.

AHP is a tool at the hands of decision makers as one of the most widely used multiple criteria decision making tools. Many studies have been done based on AHP including applications of AHP in different fields such as planning, selecting a best alternative, resource allocations, resolving conflict, optimization, etc. (Vaidya \& Kumar, 2006). Many studies have indicated that AHP can be applied form an AHP/DEA ranking model for improving DEA usability by deriving comparative weight from inputs/outputs via AHP pair wise comparison (Tseng \& Lee, 2009).

Efficiency analysis via a combined method with AHP and DEA can be performed by two approaches. In the first approach, DEA is run for each pair of units separately and then the pair wise evaluation matrix generated DEA stage is utilized to rank scale the units via AHP approach. This approach was used in many fields such as 3PL vendor selection (Zhang et al., 2006) and hotel ranking (Rouyendegh \& Erkan, 2010).

In the second approach, AHP was used to determine the weight of any qualitative criteria (input or outputs) verified and then, the DEA model was used for solving the multi-objective model to identify the best alternatives. AHP is used for the weight determination or restriction in this approach. It was used in warehouse operators selection (Korpela et al., 2007), bridge risks assessment (Wang et al., 2008),relative efficiency of greenhouse gas technologies (Lee et al., 2008), supplier performance (Yuan et al., 2008), the efficiency of R\&D management activities in universities (Feng et al., 2004) and also hydrogen R\&D programs (Lee et al., 2010), smartphone comparisons (Peaw \& Mustafa, 2006), evaluating the flexible manufacturing systems (Rezaie at al., 2010), measuring the agility of manufacturing systems (Saleeshya \& Babu, 2012).

As shown in literature review, there is no study focus on relative efficiency of commercial banks by integrated with AHP and DEA approach. Furthermore, such a study that analyzes the relative efficiency of commercial banks in Turkey can be considered an important contribution to the literature.

\section{Research Method}

\subsection{Data Envelopment Analysis}

Data Envelopment Analysis (DEA) is a non-parametric approach to efficiency measurement of similar organizational units called Decision Making Units (DMUs). Its basic foundation was generated from Farrell's (1957) original work that was later popularized by Charnes et al. (1978). DEA provides a single measure and easily deals with multiple inputs and multiple outputs (Agha et al., 2011).

DEA has two models as CCR and BCC. CCR (Charnes-Cooper-Rhodes) model is the basic DEA model which assumes constant returns to scale (CRS) was proposed by Charnes et al. (1978). This model assumes that all DMUs are operating at an optimal scale. However, Banker et al. (1984) suggested BCC (Banker-Charnes-Cooper) model as an extension of the CRS model to account for variable returns to scale (VRS) situation.

DEA models typically measure technical efficiency in one of two ways. Input oriented models measure how much each DMU can reduce its inputs while producing the original level of output. However, output oriented models measure how much each DMU can expand its output while holding inputs unchanged.

Assuming $\mathrm{n}$ DMUs with $\mathrm{m}$ inputs and s outputs, the primal output CCR and $\mathrm{BCC}$ model related to $\mathrm{DMU}_{\mathrm{k}}$ are as shown in Equations 1 and 2. Efficiency score is less than or equal to 1. When the efficiency score is 1, DMU is 
regarded as an efficient frontier.

Output Oriented CCR Model

$\min E_{k}=\sum_{r=1}^{m} v_{i} x_{i k}(1)$

$s t$

$\sum_{r=1}^{s} \mathrm{u}_{\mathrm{r}} \mathrm{y}_{\mathrm{rk}}=1$

$\sum_{r=1}^{s} \mathrm{u}_{\mathrm{r}} \mathrm{y}_{\mathrm{rj}}-\sum_{i=1}^{m} \mathrm{v}_{\mathrm{i}} \mathrm{x}_{\mathrm{ij}} \leq 0$

$\mathrm{u}_{\mathrm{r}}, \mathrm{v}_{\mathrm{i}} \geq$

$$
j=1, \ldots, n r=1, \ldots, s i=1, \ldots ., m
$$

$\mathrm{E}_{\mathrm{k}}=$ the efficiency score of $k^{\text {th }}$ DMU

$\mathrm{V}_{\mathrm{ik}}$ : weight given to $i^{\text {th }}$ input by $k^{\text {th }} \mathrm{DMU}$

$\mathrm{x}_{\mathrm{ik}}$ : amount of $i^{\text {th }}$ input utilized by $k^{\text {th }}$ DMU

$\mathrm{u}_{\mathrm{rk}}$ : weight given to $r^{\text {th }}$ output by $k^{\text {th }} \mathrm{DMU}$

$\mathrm{y}_{\mathrm{rk}}$ : amount of $r^{\text {th }}$ output produced by $k^{\text {th }} \mathrm{DMU}$

$\mathrm{x}_{\mathrm{ij}}: i^{\text {th }}$ input of the $j^{\text {th }} \mathrm{DMU}$

$\mathrm{y}_{\mathrm{rj}}: r^{\text {th }}$ output of the $j^{\text {th }} \mathrm{DMU}$

$\varepsilon$ : sufficiently small positive number (e.g. 0,00001)
Output Oriented BCC Model

$\min \mathrm{E}_{\mathrm{k}}=\left(\sum_{\mathrm{r}=1}^{\mathrm{m}} \mathrm{v}_{\mathrm{i}} \mathrm{x}_{\mathrm{ik}}\right)-\mu_{0}(2)$

st

$\sum_{r=1}^{s} \mathrm{u}_{\mathrm{r}} \mathrm{y}_{\mathrm{rk}}=1$

$\left(\sum_{r=1}^{s} \mathrm{u}_{\mathrm{r}} \mathrm{y}_{\mathrm{rj}}\right)-\left(\sum_{i=1}^{m} \mathrm{v}_{\mathrm{i}} \mathrm{x}_{\mathrm{ij}}\right)+\mu_{0} \leq 0$

$\mathrm{u}_{\mathrm{r}}, \mathrm{v}_{\mathrm{i}} \geq \mu_{0}=$ serbest

$\mathrm{j}=1, \ldots, \mathrm{nr}=1, \ldots, \mathrm{si}=1, \ldots . . \mathrm{m}$

According to Bobe (2009), DEA is a powerful tool in that because (i) it evaluates the efficiency performance of a DMU relative to other DMUs either for a period or over number of periods (benchmarking); (ii) it provides monitoring information for a specific DMU over a period of time; (iii) it suggests the benchmark DMUs (reference set) that can be used to estimate the efficient amount of resources required to achieve the same level of outputs; and (iv) it estimates the potential reductions in inputs needed to achieve the same level of outputs and/or the potential increase in outputs using the same level of inputs. There are, however, some limitations of DEA. First, the efficiency score obtained by a DMU is sensitive to the number of inputs and outputs used in the analysis. Second, classical DEA does not provide statistical inferences. Third, DEA results may be misleading. An efficiency score of 1 does not necessarily mean that the performance of a DMU is the best. It only indicates, relative to the other DMUs in the group, that the DMU is considered to be efficient. Fourth, specification of inputs and outputs may appear to be more subjective.

\subsection{Analytic Hierarchy Process}

The Analytic Hierarchy Process (AHP) enables decision makers to structure a complex problem in the form of a simple hierarchy and to evaluate a large number of quantitative and qualitative factors in a systematic manner under multiple conflicting criteria (Lee et al., 2008).

According to Saaty (2008), to make a decision in an organized way to generate priorities we need to decompose the decision into the following steps: (i) Define the problem and determine the kind of knowledge sought. (ii) Structure the decision hierarchy from the top with the goal of the decision, then the objectives from a broad perspective, through the intermediate levels (criteria) to the lowest level (alternatives). (iii) Construct a set of pairwise comparison matrices. Each element in an upper level is used to compare the elements in the level immediately below with respect to it. (iv) Use the priorities obtained from the comparisons to weight the priorities in the level immediately below. Then for each element in the level below add its weighted values and obtain its global priority.

To make comparing, AHP uses the scale for pairwise comparisons. The numbers 1, 3, 5, 7, and 9 are used as 
scaling ratios, and correspond to the strength of preference for one element over another. For example, the number 9 indicates a case of extreme importance over another element. After pairwise comparisons are conducted, the weights of the criteria are calculated and checked for consistency. Then, a review of the consistency ratio (CR) is conducted in order to ensure that it falls between 0 and 0.10 . CR is determined to be the ratio of Consistency Index (CI) to Random Index (RI). The fact that CR is determined to be greater than 0 but less than 0.10 implies a satisfactory degree of consistency in the pairwise comparisons matrix. We then aggregate the weights.

\subsection{Integrated with AHP and DEA}

Efficiency that refers to the relationship between output and input does not employ multiple inputs to produce multiple outputs because it is limited only to a single output and a single input. Hence, it is extended into weighted sum of outputs and weighted sum of inputs. So, it can be said that the key issue is how to assign weights to each input and output in the efficiency analysis. Thus, the weights, $u_{j}$ and $v_{j}$, are determined by solving the DEA model. These weights developed by DEA may not represent the same relative subjective weights that management might apply as to the relative importance of the variables (especially the output variables) used in the DEA models (Al-Delaimi \& Al-Ani, 2006). This is a significant point to management when evaluating the performance of a DMU. Thus, weights have an important effect on the efficiency of the DMU.

Literature proposes to several approaches to determine weights. Majority of them can be classified into subjective approaches and objective approaches (Ma et al., 1999). Subjective approaches determine the weights according to the preferential judgments of decision maker. Eigenvector method, weighted least square method, and Delphi method can be example for these approaches (Ma et al., 1999).On the other hand, objective approaches determine the weights by making use of mathematical models, but they neglect subjective judgment (Liu, 2003). They include principal element analysis, entropy method, and multiple objective programming model (Ma et al., 1999; Ginevicius \& Podvezko, 2004).

This paper proposes AHP as a subjective method to determine weights. The AHP approach was employed to ascertain the relative weights of the criteria. It makes use of pairwise comparison matrices, hierarchical structures, and ratio scaling to apply weights to attributes (Lee et al., 2008). The advantage of this method is that experts can reasonably identify the weight index that corresponds to the real problems (Liu, 2003). Thus, despite the different placement of weights on the index, the method can still determine the order of priority and avoid conflicts between the reality and the index weights (Liu, 2003). Furthermore,AHP which is technically valid and practically useful does not need to large sample (Lam \& Zhao, 1998). It also can be used in combination with other methods. DEA is proposed in this study to generate local weights of criteria from pairwise comparison judgment matrices used in the AHP.

\section{Model and Data}

\subsection{Input and Output Variables}

Using DEA model in measuring bank efficiency requires selection of appropriate input and output variables. However, there is no consensus in the banking literature regarding the proper selection of inputs and outputs (Rao \& Lakew, 2012). Furthermore, commercial banking is a very difficult service industry in which to measure output, technical change, or productivity growth (Berger \& Humphrey, 1992).

The choice of output and input variables is the first difficult question that must be addressed by any study on banking. Such a choice will be influenced by the selected concept of banking firm, by the particular question under consideration and, also, by the availability of data (Pastor et al., 1997). Two different approaches appear in the literature regarding the measurement of banks inputs and outputs, popularly known as production approach and intermediation approach (Berger \& Humphrey, 1997). The production approach views banks as using purchased inputs to produce deposits and various categories of bank assets. It considers to banks as institutions that use capital and labor to produce loans and deposit account services. In this approach, labor, capital and operating costs are treated as inputs and loans, deposits, and transactions are considered the outputs.

The intermediation approach, on the other hand, views banks as financial intermediaries whose primary business is to borrow funds from depositors and lend those funds to others for profit (Yue, 1992). It generally uses loans as output and various costs such as interest expense, labor, capital and operating as outputs. It views the banks as using deposits together with purchased inputs to produce various categories of bank assets. However, there is still no current consensus on which of the two methodologies outlined above should be utilized in bank efficiency analysis. We have used production approach with restricted choice of variables. 
To obtain input and output variables in this study, a preliminary list was composed using all input and output variables used in the literature. This list was shown to three branch managers of different banks who were asked to give their feedback whether the list is reasonable. Further, they were asked to add, delete or combine variables. Based on these responses, a refined list was compiled and shown again to bank administration until a consensus was reached on what variables should be used to better represent the efficiency of the department. Thus, a final list of variables was obtained. These variables are shown in Table 2. It also gives more details about the measures.

Table 2. Variables and descriptions

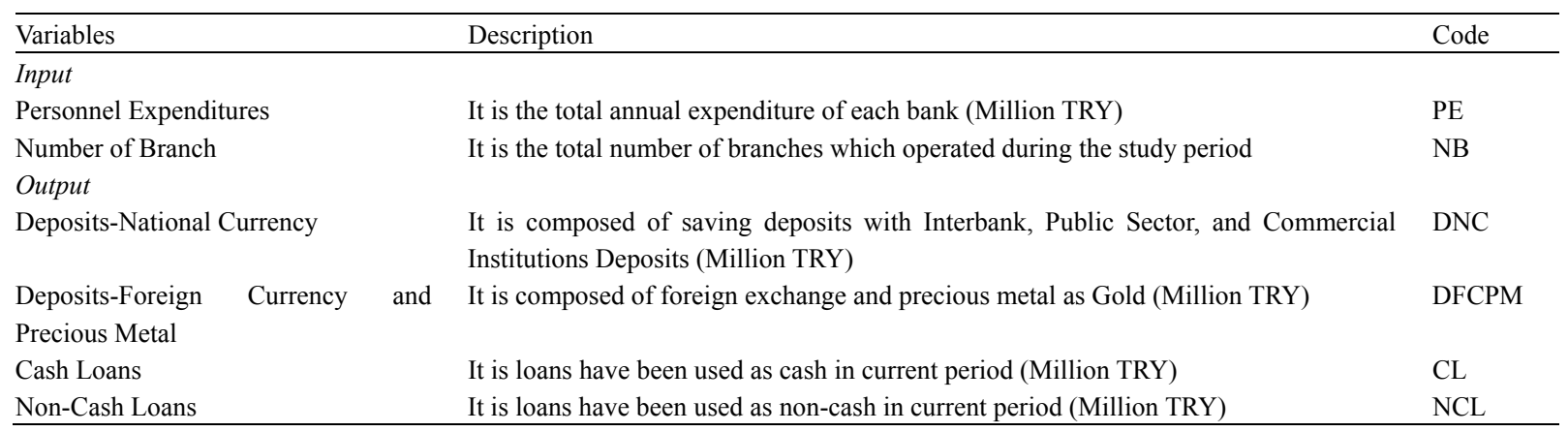

\subsection{Sample Selection}

Turkish banking system consists of three functional bank types such as commercial banks, development and investment banks, and participation banks (noninterest banking). The goal of the sample selection was to find comparable banks. Thereby, we decided to include only commercial banks and to neglect other types of banks. Commercial banks produce $92 \%$ of the Turkish banking sector's total assets (Banking Regulation and Supervision Agency, 2011). Thus, commercial banks have an important role in Turkish banking system. Bank sample was also restricted to large banks which are more than one percent market share. As the market share, it has been taken account of total assets.As a result, the thirteen of 31 commercial banks operated in Turkey were chosen as the sample. Thus, this study applies DEA to compare operational performance of 13 commercial banks in Turkey. Much information about these banks according to 2011 statistics can be seen in Table 3.

Table 3. Much information about the sample

\begin{tabular}{|c|c|c|c|c|c|c|c|}
\hline Banks* & Ownership & $\begin{array}{l}\text { Assets } \\
\text { (Million TRY) }\end{array}$ & $\begin{array}{l}\text { General Market } \\
\text { Share }(\%)^{* *}\end{array}$ & Banks* & Ownership & $\begin{array}{l}\text { Assets } \\
\text { (Million TRY) }\end{array}$ & $\begin{array}{l}\text { General Market } \\
\text { Share }(\%)\end{array}$ \\
\hline İşbankası & Private-owned & 161775 & 14.45 & Finansbank & Foreign-owned & 46199 & 4.13 \\
\hline Ziraat & State-owned & 160681 & 14.35 & Teb & Private-owned & 38092 & 3.40 \\
\hline Garanti & Private-owned & 146642 & 13.09 & Denizbank & Foreign-owned & 36032 & 3.22 \\
\hline Akbank & Private-owned & 133552 & 11.93 & Hsbc & Foreign-owned & 24172 & 2.16 \\
\hline Yapıkredi & Private-owned & 108103 & 9.65 & Ing & Foreign-owned & 21066 & 1.88 \\
\hline Halkbank & State-owned & 91404 & 8.16 & Şekerbank & Private-owned & 14400 & 1.29 \\
\hline Vakıfbank & State-owned & 89465 & 7.99 & & & & \\
\hline
\end{tabular}

Source: Banking Regulation and Supervision Agency (2011)

Notes: *Ordered by general market share. **According to total assets.

To ensure meaningful efficiency scores, the number of DMUs must be large enough relative to the number of input and output variables. A rule of thumb is given by Boussofiane et al. (1991) and Ramanathan (2003) as [N $\geq$ $2 *(\mathrm{~s}+\mathrm{m})]$, where $\mathrm{s}$ is the number of output variables, $\mathrm{m}$ is the number of input variables, and $\mathrm{N}$ is the number of DMUs. In this research, the number of DMUs (13) is more than twice the sum of the number of input and output variables. However, small sample size in this study can be compared with some of the other small sample sizes in the DEA literature (Oral \& Yolalan, 1990; Haag \& Jaska, 1995; Li, 2006; Cronje, 2007; Chen-guo et al., 2007; Akhtar et al., 2011; Rao \& Lakew, 2012).

\subsection{Data}

We use annual data compiled mainly from balance sheet and income statements of banks in database of The Banks Association of Turkey (2011) and The Banking Regulation and Supervision Agency (2012). We cover 
only thirteen out of 31 commercial banks operating in Turkey which can be seen in Table 4 . It also includes data of each bank and descriptive statistics of each variable.

Table 4. Data and descriptive statistics

\begin{tabular}{|c|c|c|c|c|c|c|c|}
\hline \multirow[b]{2}{*}{ Banks* } & \multirow[b]{2}{*}{ Code } & \multicolumn{2}{|l|}{ Inputs } & \multicolumn{4}{|c|}{ Outputs } \\
\hline & & $\mathrm{PE}$ & NB & $\mathrm{DNC}$ & DFCPM & $\mathrm{CL}$ & NCL \\
\hline Akbank & $\mathrm{DMU}_{1}$ & 1002 & 927 & 52084 & 24730 & 70213 & 14635 \\
\hline Denizbank & $\mathrm{DMU}_{2}$ & 670 & 588 & 14486 & 5580 & 22196 & 9745 \\
\hline Finansbank & $\mathrm{DMU}_{3}$ & 752 & 522 & 21446 & 7830 & 30435 & 6986 \\
\hline Garanti & $\mathrm{DMU}_{4}$ & 1248 & 914 & 49087 & 35456 & 83533 & 21022 \\
\hline Halkbank & $\mathrm{DMU}_{5}$ & 732 & 771 & 47836 & 18411 & 55236 & 17846 \\
\hline Hsbc & $\mathrm{DMU}_{6}$ & 455 & 330 & 8214 & 5033 & 13662 & 2824 \\
\hline Ing & $\mathrm{DMU}_{7}$ & 383 & 322 & 9129 & 2402 & 15265 & 5864 \\
\hline İşbankası & $\mathrm{DMU}_{8}$ & 1819 & 1201 & 61727 & 36586 & 91621 & 25850 \\
\hline Şekerbank & $\mathrm{DMU}_{9}$ & 228 & 272 & 6596 & 2482 & 8500 & 4794 \\
\hline Teb & $\mathrm{DMU}_{10}$ & 579 & 507 & 14923 & 7963 & 25444 & 8063 \\
\hline Vakıfbank & $\mathrm{DMU}_{11}$ & 834 & 680 & 46023 & 14916 & 57201 & 15664 \\
\hline Yapıkredi & $\mathrm{DMU}_{12}$ & 1138 & 907 & 35395 & 28122 & 67045 & 26135 \\
\hline Ziraat & $\mathrm{DMU}_{13}$ & 1313 & 1458 & 89866 & 23200 & 71173 & 11979 \\
\hline Mean & & 858 & 723 & 35139 & 16362 & 47040 & 13185 \\
\hline$S D$ & & 439 & 355 & 25335 & 12283 & 28835 & 7793 \\
\hline Min. & & 228 & 272 & 6596 & 2402 & 8500 & 2824 \\
\hline Max. & & 1819 & 1458 & 89866 & 36586 & 91621 & 26135 \\
\hline
\end{tabular}

Note: * Alphabetical order.

Due to the fact that operational performance was measured by outputs in banks, this study employs the output-oriented model. Efficiency Measurement System (EMS) software version 1.3 (Scheel, 2000) is used in this research to measure the technical efficiency of the departments based on both CCR and BCC models.

\section{Results}

\subsection{Weight Restrictions}

Pairwise comparison matrix should be done before the generate weight restriction. Thus, constrained weighting vectors were obtained from the AHP pairwise matrix. Then, in order to take the decision maker's preferences into the evaluation, extra constraints were added to model.

Pairwise comparison matrix were constituted based on data from three experts from three commercial banks. They work as a department manager in their banks. Data collection phase are combined using the geometric mean approach to obtain the corresponding consensus pairwise comparison judgment matrices. Finally, AHP pairwise matrix can be seen in Table 5. All the consistency rates are less than 0.10 .

Table 5. Pairwise comparison matrix for inputs and outputs

\begin{tabular}{lllllll}
\hline & PE & NB & DNC & DFCPM & CL & NCL \\
\hline PE & - & 1.00 & & & & \\
NB & 1.00 & - & & & & 1.00 \\
DNC & & & - & 2.29 & 0.37 & 1.26 \\
DFCPM & & & 0.44 & - & - & 3.63 \\
CL & & & 1.00 & 2.70 & 0.28 & - \\
NCL & & 0.27 & 0.79 & \\
\hline
\end{tabular}

Based on this matrix, new eight constraints were added to DEA models. One of them is about inputs while other is about outputs. These constraints were formed as follows:

$$
\frac{\mathrm{v}_{1 \mathrm{k}}}{\mathrm{v}_{2 \mathrm{k}}} \geq 1 \quad \frac{\mathrm{u}_{1 \mathrm{k}}}{\mathrm{u}_{2 \mathrm{k}}} \geq 1 \quad \frac{\mathrm{u}_{1 \mathrm{k}}}{\mathrm{u}_{2 \mathrm{k}}} \geq 2.29 \quad \frac{\mathrm{u}_{1 \mathrm{k}}}{\mathrm{u}_{3 \mathrm{k}}} \geq 1 \quad \frac{\mathrm{u}_{1 \mathrm{k}}}{\mathrm{u}_{4 \mathrm{k}}} \geq 3.63 \quad \frac{\mathrm{u}_{2 \mathrm{k}}}{\mathrm{u}_{3 \mathrm{k}}} \geq 0.37 \quad \frac{\mathrm{u}_{2 \mathrm{k}}}{\mathrm{u}_{4 \mathrm{k}}} \geq 1.26 \quad \frac{\mathrm{u}_{3 \mathrm{k}}}{\mathrm{u}_{4 \mathrm{k}}} \geq 3.63
$$

\subsection{Efficiency Scores}

Table 6 shows the efficiency scores and the reference set(s) for each DMU. According to CCR efficiency scores 
in the second column, four (Garanti, Halkbank, Vakıfbank, and Ziraat) of the thirteen banks under evaluation are best performers. These banks require neither input reduction nor output augmentation. However, Denizbank turned out to be the bank with the lowest performance $(0.438)$. Moreover, average CCR score of thirteen banks is 0.674 . It means that an average bank should produce $48.4 \%\left(\frac{1-0.674}{0.674}\right)$ more output with the same input level if it wishes to do business more efficiently.

Table 6. Efficiency scores, reference set and scale efficiency

\begin{tabular}{|c|c|c|c|c|c|c|}
\hline \multirow[t]{2}{*}{ DMUs } & \multicolumn{2}{|c|}{ CCR Model } & \multicolumn{2}{|l|}{ BCC Model } & \multirow{2}{*}{$\begin{array}{l}\text { Scale } \\
\text { Efficiency }\end{array}$} & \multirow{2}{*}{$\begin{array}{l}\text { Returns } \\
\text { to Scale }\end{array}$} \\
\hline & $\begin{array}{l}\text { Efficiency } \\
\text { Scores }\end{array}$ & $\begin{array}{l}\text { Reference } \\
\text { Set }\end{array}$ & Efficiency Scores & $\begin{array}{l}\text { Reference } \\
\text { Set }\end{array}$ & & \\
\hline Akbank $\left(\mathrm{DMU}_{1}\right)$ & 0.943 & $\begin{array}{l}\mathrm{DMU}_{5}(0.63) \\
\mathrm{DMU}_{11}(0.65)\end{array}$ & 0.999 & $\begin{array}{l}\mathrm{DMU}_{13}(0.15) \\
\mathrm{DMU}_{5}(0.50) \\
\mathrm{DMU}_{4}(0.35)\end{array}$ & 0.944 & DRS \\
\hline Denizbank $\left(\mathrm{DMU}_{2}\right)$ & 0.438 & $\begin{array}{l}\mathrm{DMU}_{5}(0.24) \\
\mathrm{DMU}_{11}(0.59)\end{array}$ & 0.464 & $\begin{array}{l}\mathrm{DMU}_{5}(0.11) \\
\mathrm{DMU}_{11}(0.63) \\
\mathrm{DMU}_{9}(0.26)\end{array}$ & 0.944 & IRS \\
\hline Finansbank $\left(\mathrm{DMU}_{3}\right)$ & 0.656 & $\begin{array}{l}\mathrm{DMU}_{11}(0.73) \\
\mathrm{DMU}_{4}(0.03)\end{array}$ & 0.752 & $\begin{array}{l}\mathrm{DMU}_{11}(0.61) \\
\mathrm{DMU}_{9}(0.39)\end{array}$ & 0.872 & IRS \\
\hline Garanti $\left(\mathrm{DMU}_{4}\right)$ & 1.000 & & 1.000 & & 1.000 & CRS \\
\hline Halkbank $\left(\mathrm{DMU}_{5}\right)$ & 1.000 & & 1.000 & & 1.000 & CRS \\
\hline $\mathrm{Hsbc}\left(\mathrm{DMU}_{6}\right)$ & 0.451 & $\begin{array}{l}\mathrm{DMU}_{11}(0.14) \\
\mathrm{DMU}_{4}(0.25)\end{array}$ & 0.817 & $\begin{array}{l}\mathrm{DMU}_{11}(0.14) \\
\mathrm{DMU}_{9}(0.86)\end{array}$ & 0.552 & IRS \\
\hline Ing $\left(\mathrm{DMU}_{7}\right)$ & 0.510 & $\begin{array}{l}\mathrm{DMU}_{5}(0.06) \\
\mathrm{DMU}_{11}(0.41)\end{array}$ & 0.925 & $\begin{array}{l}\mathrm{DMU}_{11}(0.12) \\
\mathrm{DMU}_{9}(0.88)\end{array}$ & 0.551 & IRS \\
\hline İşbankası $\left(\mathrm{DMU}_{8}\right)$ & 0.874 & $\begin{array}{l}\mathrm{DMU}_{11}(0.90) \\
\mathrm{DMU}_{4}(0.65)\end{array}$ & 1.000 & & 0.874 & IRS \\
\hline Şekerbank $\left(\mathrm{DMU}_{9}\right)$ & 0.485 & $\mathrm{DMU}_{5}(0.31)$ & 1.000 & & 0.485 & DRS \\
\hline Teb $\left(\mathrm{DMU}_{10}\right)$ & 0.559 & $\begin{array}{l}\mathrm{DMU}_{5}(0.20) \\
\mathrm{DMU}_{11}(0.52)\end{array}$ & 0.630 & $\begin{array}{l}\mathrm{DMU}_{11}(0.57) \\
\mathrm{DMU}_{9}(0.43)\end{array}$ & 0.887 & IRS \\
\hline Vakıfbank $\left(\mathrm{DMU}_{11}\right)$ & 1.000 & & 1.000 & & 1.000 & CRS \\
\hline Yapıkredi $\left(\mathrm{DMU}_{12}\right)$ & 0.801 & $\begin{array}{l}\mathrm{DMU}_{11}(1.06) \\
\mathrm{DMU}_{4}(0.20)\end{array}$ & 0.832 & $\begin{array}{l}\mathrm{DMU}_{13}(0.04) \\
\mathrm{DMU}_{5}(0.22) \\
\mathrm{DMU}_{4}(0.74)\end{array}$ & 0.963 & DRS \\
\hline Ziraat $\left(\mathrm{DMU}_{13}\right)$ & 1.000 & & 1.000 & & 1.000 & CRS \\
\hline Mean & 0.674 & & 0.834 & & 0.852 & \\
\hline$S D$ & 0.235 & & 0.173 & & 0.190 & \\
\hline Min. & 0.438 & & 0.464 & & 0.485 & \\
\hline $\operatorname{Max}$ & 1.000 & & 1.000 & & 1.000 & \\
\hline
\end{tabular}

The third column includes the corresponding reference units for the inefficient DMUs and the $\lambda$ values which are the raw weights assigned to peer units when solving the DEA optimization problem. The higher the contribution, the closer in performance is the peer to the unit under consideration (Marschall \& Flessa, 2008). For example, Akbank can virtually become efficient by combining the Halkbank and Vakıfbank as peers, with weights of 0.63 and 0.65 respectively. Vakifbank is the peer unit with the highest value in the reference set and thus the most comparable unit according to CCR results.

According to BCC results, six banks (Garanti, Halkbank, İşbankası, Şekerbank, Vakıfbank, and Ziraat) operate with technical efficiency. Moreover, average BCC score of thirteen banks is 0.834. It means that an average bank should produce $19.9 \%$ more output with the same input level if it wishes to do business more efficiently.

In terms of the reference set, Vakıfbank and Şekerbank are the most comparable units with their reference number in BCC efficient banks. Denizbank, which has the lowest BCC efficiency score, can virtually become efficient by combining the Halkbank, Vakıfbank, and Şekerbank as peers, with weights of $0.11,0.63$, and 0.25 respectively.

Scale efficiency shows how close or far the size of the DMU is from its optimal size (Sporcic et al., 2009). So, scale efficiency scores allow for some interesting remarks. It can be said that the average efficient score is 0.852 
based on the scale efficiency results. It means that an average bank should increase their relative efficiency on average by $17.4 \%$ if it adapted their size or volume of activities to the optimal value. The size and volume of activities of four banks (Garanti, Halkbank, Vakıfbank, and Ziraat) are well balanced because they have the efficiency of $100 \%$. However, other banks, which have the efficiency values lower than $100 \%$, partly under influence of size or volume of activities.

The issue of scale inefficiencies is explored with greater detail by considering returns to scale indicators. Among 13 banks, 6 banks operate under increasing returns to scale (IRS), 4 banks operate under constant returns to scale (CRS), and the remaining 3 banks operate under decreasing returns to scale (DRS). Both CCR efficiency and scale efficiency are equal to 1 are considered as operating at the most productive scale size.

Relatively scale efficient banks are also efficient according to CCR model. However, two banks (İşbankası \& Şekerbank) are efficient only according to the BCC model. They do not show the same efficiency level in terms of scale efficiency. According to it, it can be said that their inadequate size or volume of activities expressed by the main parameters of their performance (Sporcic et al., 2009). In other words, the banks of İşbankası and Şekerbank which are efficient on BCC model but inefficient on CCR model have been efficiently operated except the effect of scale. The major causes of inefficiency are from scale inefficiency. In other words, they operate locally efficiently whereas its overall technical inefficiency is caused by its failure to achieve scale efficiency. These banks should enhance their own efficiency by increasing their input level as these have IRS characteristics.

Akbank, Şekerbank, and Yapıkredi showing DRS characteristics should decrease of their inputs or the increase of their outputs because they have been operated by the inputs over optimal scale. In the cases of the banks of which both BCC efficiency and scale efficiency is less than 1, both can be the causes of inefficiency (So et al., 2007).

\subsection{Potential Improvements}

One of the attractiveness of DEA is that it provides reference set so that inefficient DMUs have benchmark DMU to learn from their experiences (Bobe, 2009). So, in addition to providing efficiency measures, DEA also provides other information relevant for the inefficient DMUs. Because efficient DMUs do not have any slack, this information is only of interest for inefficient DMUs (Tongzon, 2011).

Table 7 shows the banks' target input/output data and projection obtained from the DEA calculations. A DMU is $\mathrm{BCC}$ efficient if it has no input excesses and no output shortfalls. Thus, the difference between original data and projection is $0.00 \%$. So, it can be seen the potential improvements for the seven inefficient banks under BCC model (Marschall and Flessa, 2008).

Table 7. Target values (\%) for inefficient banks according to BCC model

\begin{tabular}{|c|c|c|c|c|c|c|c|c|c|c|c|c|}
\hline \multirow[b]{3}{*}{ DMUs } & \multicolumn{4}{|c|}{ Inputs } & \multicolumn{8}{|c|}{ Outputs } \\
\hline & \multicolumn{2}{|c|}{$\mathrm{PE}$} & \multicolumn{2}{|l|}{ NB } & \multicolumn{2}{|c|}{ DNC } & \multicolumn{2}{|c|}{ DFCPM } & \multirow{2}{*}{$\frac{\mathrm{CL}}{\text { Target }}$} & \multicolumn{3}{|c|}{ NCL } \\
\hline & Target & $\%$ & Target & $\%$ & Target & $\%$ & Target & $\%$ & & $\%$ & Target & $\%$ \\
\hline $\mathrm{DMU}_{1}$ & 1002 & 0 & 927 & 0 & 52152 & 0.1 & 24762 & 0.1 & 70305 & 0.1 & 18048 & 23.3 \\
\hline $\mathrm{DMU}_{2}$ & 670 & 0 & 588 & 0 & 31195 & 115.4 & 12017 & 115.4 & 47800 & 115.4 & 20985 & 115.4 \\
\hline $\mathrm{DMU}_{3}$ & 599 & -20.3 & 522 & 0 & 28506 & 32.9 & 10408 & 32.9 & 40454 & 32.9 & 11454 & 64.0 \\
\hline $\mathrm{DMU}_{6}$ & 314 & -31.0 & 330 & 0 & 10059 & 22.5 & 6163 & 22.5 & 16731 & 22.5 & 6339 & 124.5 \\
\hline $\mathrm{DMU}_{7}$ & 302 & -21.0 & 322 & 0 & 9865 & 8.1 & 2596 & 8.1 & 16495 & 8.1 & 6337 & 8.1 \\
\hline $\mathrm{DMU}_{10}$ & 577 & -0.4 & 507 & 0 & 23685 & 58.7 & 12639 & 58.7 & 40382 & 58.7 & 12796 & 58.7 \\
\hline $\mathrm{DMU}_{12}$ & 1138 & 0 & 907 & 0 & 42545 & 20.2 & 33803 & 20.2 & 80588 & 20.2 & 31414 & 20.2 \\
\hline
\end{tabular}

The projections suggest that particularly the analyzed banks are too big to be efficient. The results demonstrate that the efficiency of Denizbank which is the most inefficient can be improved when the personnel expenditure (PE) is reduced by $53.6 \%$. Similarly, its efficiency can be attained if all of the output values are increased by $115.4 \%$. When the number of branches (NB) is analyzed, it is seen that any DMU doesn't have to decrease it. So, it can be said that banks are working with optimal number of branches.

For inefficient banks to benefit from the study, the amounts by which these DMUs should increase their outputs to become efficient are calculated using the BCC model. In this study, the targeted value of a variable represents the amount to which a given DMU can increase its production of that specific variable. In the following figures (Figure 2-3-4-5), the light columns indicates the actual value of outputs while dark column indicates potential improvements to enhance required output amount. 


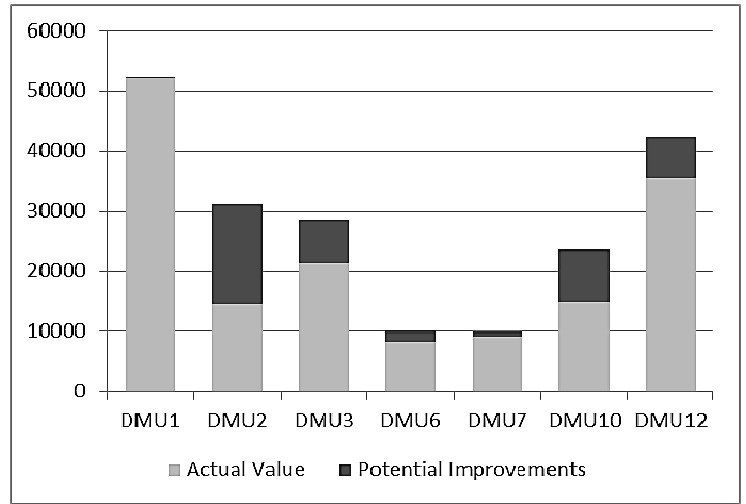

Figure 2. Actual values and potential improvements of deposits-national currency (DNC)

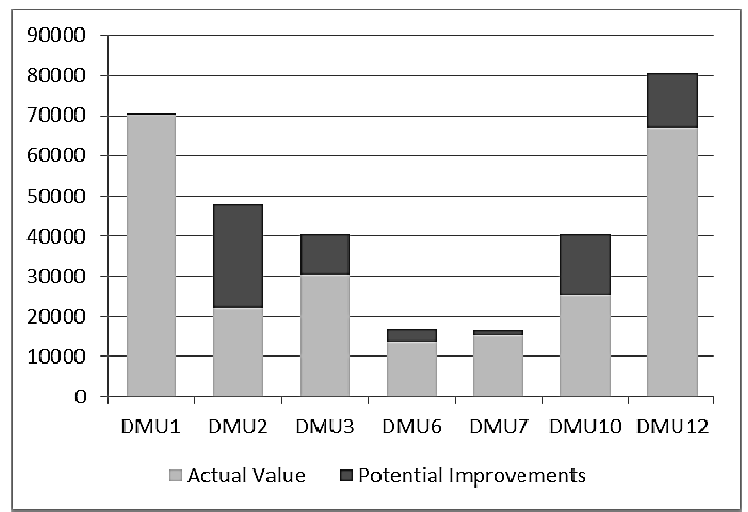

Figure 4. Actual values and potential improvements of cash loans $(\mathrm{CL})$

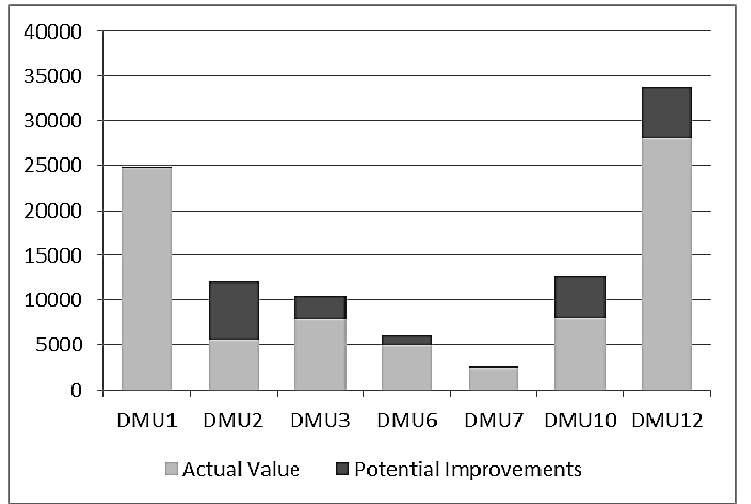

Figure 3. Actual values and potential improvements of deposits-foreign currency and precious metal

(DFCPM)

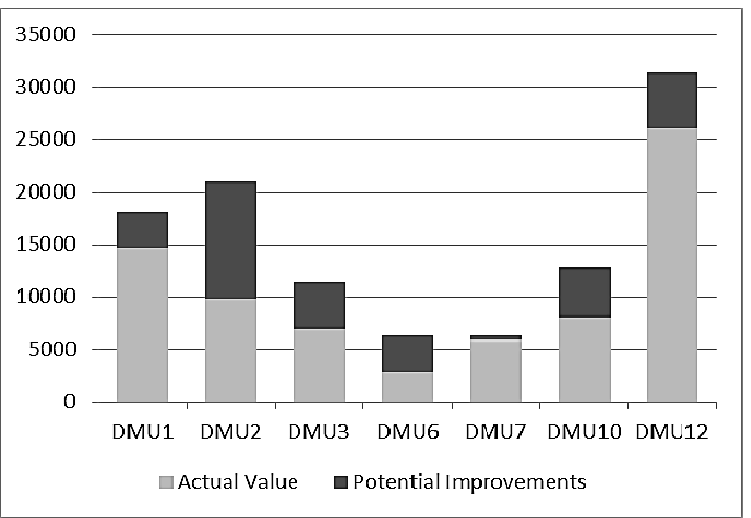

Figure 5. Actual values and potential improvements of non-cash loans (NCL)

Figure 2 shows the actual values and the potential improvements of the Deposits-National Currency (DNC). It is noticed that Denizbank and Teb requires the highest increase respectively as 16709 and 8761 million TRY. Akbank, Finansbank, Hsbc, Ing, and Yapıkredi should increase their DNC by certain amounts to reach the target value in order to be efficient. Akbank is the nearest bank to target value by 68 million TRY.

As for Deposits-Foreign Currency and Precious Metal (DFCPM), Figure 3 shows the actual and target values for this output. If inefficient departments can enhance their outputs to the corresponding potential improvement levels, then, they would become more efficient. In parallel with this, Denizbank, Yapikredi, Teb, Finansbank, Hsbc, Ing, and Akbank need to enhance their DFCPM respectively in order to become more efficient.

When potential improvement of Cash Loans (CL) is analyzed in Figure 4, it is seen that Denizbank, Teb, and Yapıkredi are the banks need to the most improvements as 24604, 14138, and 13543 million TRY respectively. However, Akbank and Ing need to less improvements of CL than other inefficient banks.

In figure 5, it is demonstrated actual value and potential improvement of non-cash loans (NCL). Akbank is also closer to target values than other inefficient banks in terms of NCL. However, Denizbank is the farthest bank from target values by 11240 million TRY. 


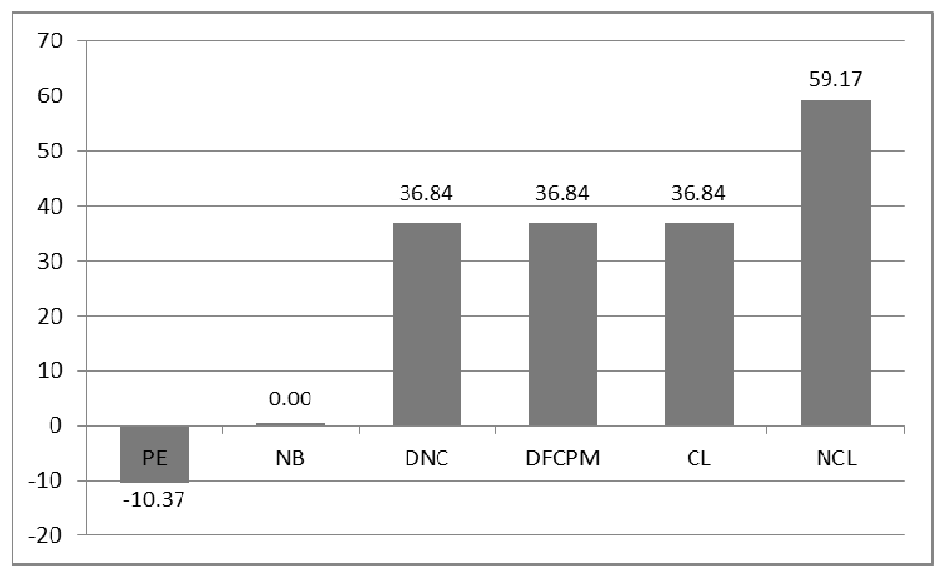

Figure 6. Average improvement rate (\%) of input and output value for inefficient banks

Figure 6 indicates the average improvement rates of both inputs and outputs for efficient. According to it, three of the four outputs, DNC, DFCPM, and CL, have same (36.84\%) average improvement rate. On the other hand, NCL have been expanded to average $59.17 \%$ by inefficient banks. With respect to average input decreasing, it is interesting note that inefficient banks have not to change their NBs. However, PE should reduce average 10.37\% by inefficient banks. Thus, these banks can produce same level outputs with less PE.

\section{Discussion and Conclusion}

This study measure the relative efficiency of 13 commercial banks in Turkey. It combines the AHP and DEA to create a suitable performance evaluation model for these banks. The fact that all the products and services are similar for all banks ensures maximum feasible comparability among banks. Therefore, any observed difference in efficiency should be explained by differences in technical efficiency and not in lack of comparability. The following findings and insights from CCR and BCC model are summarized.

Nine banks are identified as being inefficient according to the CCR model while seven banks are identified according to the BCC. It is noted that BCC yields more efficient banks than CCR. These results are expected due to two reasons according to Agha et al. (2011). First, theoretically the numerator of BCC ratio is greater than the numerator in CCR. Secondly, BCC relaxes the slack variables to be greater than zero and adding lambda constraint. Further, the values of CCR and BCC efficiencies are close to each other, which imply that either the CCR or BCC may be adopted for this research.

Three state-owned banks (Halkbank, Ziraat, and Vakıfbank) are efficient in both CCR and BCC model. Moreover, these banks operate at the most productive scale size according to scale efficiency. These results are similar to empirical results from Aydin et al. (2009) shows that the most efficient banks in Turkey are state-owned banks. However, foreign-owned banks have the lower efficiency scores than both state-owned and private-owned banks.

The results of the analysis show a first insight into the inefficient banks. They should especially improve their non-cash loans. Furthermore, they should focus on their annual personnel expenditure. Moreover, more than half $(64.3 \%)$ of the banks are scale inefficiency. These banks should improve tactical actions according to their working region (IRS or DRS).

This study has some limitations that need to be acknowledged, but which at the same time lend themselves towards identifying future research avenues. First of all, the quality of the DEA results depends heavily on the choice of the input/output measures. So, quality related measures such as customer satisfaction or responsiveness should also be included to the models. In this regard, future studies could also try to develop for qualitative outputs such as customer satisfaction, customer responsiveness, and service quality and apply DEA for investigating their productivity impact. Furthermore, models that further add similar constraints on the input multipliers, based on personnel salary, were used to identify cost efficient banks. Future researches could also investigate whether the same conclusions can be replicated and generalized in different bank segments such as participation, development and investment and/or countries.

Another limitation is the choice of variables for inclusion in a DEA analysis. In literature a lot of studies focus on bank efficiency analysis with DEA. These studies use various inputs and outputs set. While this is largely left up to management judgment, there should be a more rigorous method for selecting input and output variables for 
productivity assessment. Therefore, future researchers may focus on developing a framework for input/output variable selection.

One limitation is that this study has not implications from a customer's perspective. Technical efficiency can vary widely across commercial banks. So, in future studies, the model should be expanded to customer perspective with including related outputs such as customer satisfaction, transactions time.

A last limitation is about some special problems of DEA. Since it is a deterministic procedure, it does not provide fit statistics such as r-square or p-value that can be used for statistical inferences. Moreover, there is no role for statistical error in the calculations and a number of questions need to be answered about the validity of the DEA score.

Managerial relevance of our research is quite important. It is widely accepted that to succeed a company must perform well. Moreover, the simplicity of the results, and the fact that they arise directly from observed input/output data that allow for better acceptance of the results by the bank managers. Bank management should pay more attention to personnel expenditure among the input variables and non-cash loans among the output variables. Furthermore, managers can use DEA to compare their business units.

\section{References}

Agha, S. R., Kuhail, I., Abdelnabi, N., Salem, M., \& Ghanim, A. (2011). Assessment of academic departments efficiency using data envelopment analysis. Journal of Industrial Engineering and Management, 4(2), 301-3235. http://dx.doi.org/10.3926/jiem.2011.v4n2.p301-325

Akhtar, M. F., Ali, K., \& Sadaqat, S. (2011). Performance efficiency of commercial banks of Pakistan: nonparametric technique data envelopment analysis (DEA). Asian Journal of Business and Management Sciences, 1(2), 150-156.

Al-Delaimi, K. S. K., \& Al-Ani, A. H. B. (2006). Using data envelopment analysis to measure cost efficiency with an application of Islamic banks. Scientific Journal of Administrative Development, 4, 134-156.

Al-Faraj, T., Alidi, A., \& Bu-Bshait, K. (1993). Evaluation of bank branches by means of data envelopment analysis. International Journal of Operations \& Production Management, 13(9), 45-52. http://dx.doi.org/10.1108/01443579310043628

AlKhathlan, K., \& Malik, S. A. (2010). Are Saudi banks efficient? Evidence using data envelopment analysis (DEA). International Journal of Economics and Finance, 2(2), 53-58.

Allen, L., \& Rai, A. (1996). Operational efficiency in banking: an international comparison. Journal of Banking and Finance, 20, 655-672. http://dx.doi.org/10.1016/0378-4266(95)00026-7

Al-Shammari, M., \& Salimi, A. (1998). Modeling the operating efficiency of banks: a nonparametric methodology. Logistics Information Management, 11, 5-12. http://dx.doi.org/10.1108/09576059810202196

Altunbas, Y., \& Molyneux, P. (1996). Economies of scale and scope in European banking. Applied Financial Economics, 6, 367-375. http://dx.doi.org/10.1080/096031096334187

Athanassopoulos, A. D. (1997). Service quality and operating efficiency synergies for management control in the provision of financial services: evidence from Greek bank branches. European Journal of Operational Research, 98, 300-313. http://dx.doi.org/10.1016/S0377-2217(96)00349-9

Avkiran, N. K. (1999). The evidence on efficiency gains: the role of mergers and the benefits to the public. Journal of Banking and Finance, 23, 991-1013. http://dx.doi.org/10.1016/S0378-4266(98)00129-0

Aydin, N., Yalama, A., \& Sayim, M. (2009). Banking efficiency in developing economy: empirical evidence from Turkey. Journal of Money, Investment and Banking, 8, 49-70.

Ayranci, E. (2011). The efficiency of the private commercial banking sector in Turkey: a managerial approach. Journal of International Business and Cultural Studies, 4, 1-25.

Banker, R. D., Charnes, A., \& Cooper, W. W. (1984). Some models for estimating technical and scale inefficiencies in data envelopment analysis. Management Science, 30(9), 1078-1092. http://dx.doi.org/10.1287/mnsc.30.9.1078

Banking Regulation and Supervision Agency. (2011). Bankacllikta yapısal gelişmeler. Retrieved from http://www.bddk.org.tr/WebSitesi/turkce/Raporlar/Bankacilikta_Yapisal_Gelismeler/11085bygr_2011.pdf

Banking Regulation and Supervision Agency. (2012). Fintürk [Data file]. Retrieved from http://ebulten.bddk.org.tr/haritalama/harita.aspx 
Barr, R. S., Killgo, K. A., Siems, T. F., \& Zimmel, S. (2002). Evaluating the productive efficiency and performance of U.S. commercial banks. Managerial Finance, 28(8), 3-25. http://dx.doi.org/10.1108/03074350210767988

Berg, S. A., Forsund, F. R., Hjalmarsson, L., \& Suominen, M. (1993). Banking efficiency in the Nordic countries. Journal of Banking and Finance, 17, 371-88. http://dx.doi.org/10.1016/0378-4266(93)90038-F

Berger, A. N., \& Humphrey, D. B. (1992). Measurement and efficiency issues in commercial banking. In Z. Griliches (Ed.), Output Measurement in the Service Sectors. University of Chicago Press.

Berger, A. N., \& Humphrey, D. B. (1997). Efficiency of financial institutions: international survey and directions for future research. European Journal of Operational Research, 98(2), 175-212. http://dx.doi.org/10.1016/S0377-2217(96)00342-6

Bobe, B. (2009). Evaluating the efficiencies of university faculties: adjusted data envelopment analysis. Paper for Accounting and Finance Association of Australia and New Zealand (AFAANZ) 2009 Conference, Adelaide, Australia, 5-7 July.

Boussofiane, A., Dyson, R., \& Rhodes, E. (1991). Applied DEA. European Journal of Operational Research, 2(6), 1-15. http://dx.doi.org/10.1016/0377-2217(91)90331-O

Chansarn, S. (2008). The relative efficiency of commercial banks in Thailand: DEA approach. International Research Journal of Finance and Economics, 18, 53-68.

Charnes, A., Cooper, W. W., \& Rhodes, E. (1978). Measuring the efficiency of DMUs. European Journal of Operational Research, 2, 429-444. http://dx.doi.org/10.1016/0377-2217(78)90138-8

Chen-guo, D., Ting, L., \& Jie, W. (2007). Efficiency analysis of China's commercial banks based on DEA: negative output investigation. Chine-USA Business Review, 6(2), 50-56.

Cronje, T. (2007). Assessing the relative efficiency management of South African banks. Management Dynamics, 16, 11-23.

Dekker, D., \& Post, T. (2001). A quasi-concave DEA model with an application for bank branch performance evaluation. European Journal of Operational Research, 132, 296-311. http://dx.doi.org/10.1016/S0377-2217(00)00153-3

Denizer, C., Dinç, M., \& Tarimcilar, M. (2000). Measuring Banking Efficiency in the Pre- and Post-Liberalization Environment: Evidence from the Turkish Banking System. World Bank Research Working Papers, No. 2476.

Farrell, M. J. (1957). The measurement of productive efficiency. Journal of the Royal Statistical Society, 120(3), 253-281. http://dx.doi.org/10.2307/2343100

Feng, Y. J., Lu, H., \& Bi, K. (2004). An AHP/DEA method for measurement of the efficiency of R\&D management activities in universities. International Transactions in Operational Research, 11, 181-191. http://dx.doi.org/10.1111/j.1475-3995.2004.00450.x

Ginevicius, R., \& Podvezko, V. (2004). Objective and subjective approaches to determining the criterion weight in multicriteria models. Proceedings of International Conference RelSat, 04, 133-139.

Golany, B., \& Storbeck, J. E. (1999). A data envelopment analysis of the operational efficiency of bank branches. Interfaces, 2(3), 14-26. http://dx.doi.org/10.1287/inte.29.3.14

Grigorian, D. A., \& Manole, V. (2002). Determinants of commercial bank performance in transition: an application of data envelopment analysis. World Bank Policy Research Working Paper2850, June.

Haag, S. E., \& Jaska, P. V. (1995). Interpreting inefficiency rating: an application of bank branch operating efficiencies. Managerial and Decision Economics, 16, 7-14. http://dx.doi.org/10.1002/mde.4090160103

Halkos, S. E., \& Salamouris, D. S. (2004). Efficiency measurement of the Greek commercial banks with the use of financial ratios: A data envelopment analysis approach. Management Accounting Research, 15(2), 201-224. http://dx.doi.org/10.1016/j.mar.2004.02.001

Isik, I., \& Hassan, M. K. (2000). Technical, scale and allocative efficiencies of Turkish banking industry. Journal of Banking and Finance, 26(4), 719-766. http://dx.doi.org/10.1016/S0378-4266(01)00167-4

Jackson, P. M., \& Fethi, M. D. (2000). Evaluating the efficiency of Turkish commercial banks: an application of dea and tobit analysis. Efficiency and Productivity Research Unit (EPRU) Discussion Paper, University of Leicester, UK. 
Ji, K., Song, W., \& Wang, R. (2012). Research on China's commercial banks rating and ranking based on DEA. American Journal of Operations Research, 2, 122-125. http://dx.doi.org/10.4236/ajor.2012.21014

Korpela, J., Lehmusvaara, A., \& Nisonen, J. (2007). Warehouse operator selection by combining AHP and DEA methodologies. International Journal of Production Economics, 108(1-2), 135-142. http://dx.doi.org/10.1016/j.ijpe.2006.12.046

Kuosmanen, T., \& Post, T. (2001). Measuring economic efficiency with incomplete price information: with an application to European commercial banks. European Journal of Operational Research, 134, 43-58. http://dx.doi.org/10.1016/S0377-2217(00)00237-X

Lam, K., \& Zhao, X. (1998). An application of quality function deployment to improve the quality of teaching. International Journal of Quality Reliability Management, 15(4), 389-413. http://dx.doi.org/10.1108/02656719810196351

Lee, S. K., Mogi, G., Shin, S. C., \& Kim, J. W. (2008). Measuring the relative efficiency of greenhouse gas technologies: an AHP/DEA hybrid model approach. Proceedings of the International MultiConference of Engineers and Computer Scientists, 2, 19-21 March, Hong Kong.

Lee, S., Kim, J., Mogi, G., \& Hui, K. S. (2010). Fuzzy AHP/ DEA approach with scale efficiency for measuring the relative efficiency of hydrogen R\&D programs in the sector of developing hydrogen energy technologies. Proceedings of the 18th World hydrogen energy conference, May 16-21, Essen, Germany.

$\mathrm{Li}, \mathrm{Z}$. (2006). The assessment analysis of efficiency of commercial banks based on DEA model. International Management Review, 2(4), 60-66.

Liu, C. C. (2003). Simulating weights restrictions in data envelopment analysis by the subjective and objective integrated approach. Web Journal of Chinese Management Review, 6(1), 68-78.

Lovell, C. A. K., \& Pastor, J. T. (1997). Target setting: an application to a bank branch network. European Journal of Operational Research, 98, 290-299. http://dx.doi.org/10.1016/S0377-2217(96)00348-7

Ma, J., Fan, Z. P., \& Huamg, L. H. (1999). A subjective and objective integrated approach to determine attributeweights. European Journal of Operational Research, 112, 397-404. http://dx.doi.org/10.1016/S0377-2217(98)00141-6

Maea, S. F. (2010). The efficiency of the commercial banks in six pacific island countries, doctorate dissertation in school of economics and finance, Massey University. Palmerston North, New Zealand.

Malhotra, R., Malhotra, D. K., \& Lafond, C. A. (2009). Analyzing financial services industry using data envelopment analysis. International Journal of Applied Management Science, 1(3), 217-246. http://dx.doi.org/10.1504/IJAMS.2009.023703

Mansoury, A., \& Salehi, M. (2011). Efficiency analysis and classification of bank by using data envelopment analysis (DEA) model: evidence of Iranian bank. International Journal of the Physical Sciences, 6(13), 3205-3217.

Marschall, P., \& Flessa, S. (2008). Assessing the efficiency of rural health centers in Burkina Faso: an application of data envelopment analysis. Journal of Public Health, 17(2), 87-95. http://dx.doi.org/10.1007/s10389-008-0225-6

Maudos, J., Pastor, J. M., Perez, F., \& Quesada, J. (2002). Cost and profit efficiency in european banks. Journal of International Financial Markets, Institutions and Money, 12, 33-58. http://dx.doi.org/10.1016/S1042-4431(01)00051-8

Moffat, B., \& Valadkhani, A. (2009). A data envelopment analysis of financial institutions in Botswana. Oxford Business \& Economics Conference, June 24-26, St. Hugh's College, Oxford University, Oxford, UK.

Navabakhsh, M., Jahanshahloo, G. R., Lotfi, F. H., Allahviranloo, T., Balf, F. R., \& Rezai, H. Z. (2007). Finding suitable benchmark for inefficient commercial bank branches, application of DEA. International Journal of Contemporary Mathematic Sciences, 2(4), 183-193.

Oral, M., \& Yolalan, R. (1990). An empirical study on measuring operating efficiency and profitability of bank branches. European Journal of Operational Research, 46, 282-294. http://dx.doi.org/10.1016/0377-2217(90)90002-S

Ozkan-Gunay, E. N., \& Tektas, A. (2006). Efficiency analysis of the Turkish banking sector in precrisis and crisis period: a DEA approach. Contemporary Economic Policy, 24(3), 418-431. 
http://dx.doi.org/10.1093/cep/byj028

Pastor, J. M., Perez, F., \& Quesada, J. (1997). Efficiency analysis in banking firms: an international comparison. $\begin{array}{lllll}\text { European Journal of } & \text { Operational }\end{array}$ http://dx.doi.org/10.1016/S0377-2217(96)00355-4

Peaw, T. L., \& Mustafa, A. (2006). Incorporating AHP in DEA analysis for smartphone comparisons. Proceedings of the 2nd IMT-GT Regional Conference on Mathematics, Statistics, and Applications, Universiti Sains Malaysia, June 13-15, Penang, Malaysia.

Percin, S., \& Ayan, T. Y. (2006). Measuring efficiency of commercial banks in a developing economy. Investment Management and Financial Innovations, 3(2), 217-231.

Porembski, M., Breitenstein, K., \& Alpar, P. (2005). Visualizing efficiency and reference relations in data envelopment analysis with an application to the branches of a German bank. Journal of Productivity Analysis, 23, 203-221. http://dx.doi.org/10.1007/s11123-005-1328-5

Portela, M. C. A. S., \& Thanassoulis, E. (2005). Profitability of a sample of Portuguese bank branches and its decomposition into technical and allocative components. European Journal of Operational Research, 162, 850-866. http://dx.doi.org/10.1016/j.ejor.2003.10.018

Ramanathan, R. (2003). An introduction to data envelopment analysis. Sage Publications.

Rao, K. R. M., \& Lakew, T. B. (2012). Cost efficiency and ownership structure of commercial banks in Ethiopia: an application of non-parametric approach. European Journal of Business and Management, 4(10), 36-47.

Rezaie, K., Nazari-Shirkouhi, S., Alem, S. M., \& Hatami-Shirkouhi, L. (2010). Using data envelopment analysis and analytical hierarchy process model to evaluate flexible manufacturing systems. Australian Journal of Basic and Applied Sciences, 4(12), 6461-6469.

Rouyendegh, B. D., \& Erkan, T. E. (2010). The DEA-AHP hybrid ranking model applied 4 star hotels in Ankara. Gazi Üniversitesi İktisadi Ve İdari Bilimler Fakültesi Dergisi, 12(3), 69-90.

Saaty, T. L. (2008). Decision making with the analytic hierarchy process. International Journal of Services Sciences, 1(1), 83-98. http://dx.doi.org/10.1504/IJSSCI.2008.017590

Saha, A., \& Ravisankar, T. S. (2000). Rating of Indian commercial banks: a DEA approach. European Journal of Operational Research, 124, 187-203. http://dx.doi.org/10.1016/S0377-2217(99)00167-8

Saleeshya, P. G., \& Babu, A. S. (2012). A combined AHP-and DEA-based approach to measure agility of manufacturing systems. International Journal of Business and Systems Research, 6(4), 431-455. http://dx.doi.org/10.1504/IJBSR.2012.049472

Sathye, M. (2003). Efficiency of banks in a developing economy: the case of India. European Journal of Operational Research, 148, 662-671. http://dx.doi.org/10.1016/S0377-2217(02)00471-X

Scheel, H. (2000). Efficiency Measurement System Software EMS. (Version 1.3.0) [Computer Software]. Retrieved from http://www.holger-scheel.de/ems/ems_130.zip

Sherman, H., \& Ladino, G. (1995). Managing bank productivity using data envelopment analysis (DEA). Interfaces, 25, 60-73. http://dx.doi.org/10.1287/inte.25.2.60

So, S. H., Kim, J. J., Cho, G., \& Kim, D. K. (2007). Efficiency analysis and ranking of major container ports in northeast Asia: an application of data envelopment analysis. International Review of Business Research Papers, 3(2), 486-503.

Sporcic, M., Martinic, I., Landekic, M., \& Lovric, M. (2009). Measuring efficiency of organizational units in forestry by nonparametric model. Crotia Journal for Engineering, 30(1), 1-13.

Subramanyam, T., \& Reddy, C. S. (2008). Measuring the risk efficiency in Indian commercial banking-a DEA approach. East-West Journal of Economics and Business, 11(1-2), 76-105.

Tahir, I. M., Abu Bakar, N. M., \& Haron, S. (2009). Evaluating efficiency of Malaysian banks using data envelopment analysis. International Journal of Business and Management, 4(8), 96-106.

Taylor, W. M., Thompson, R. G., Thrall, R. M., \& Dharmapala, P. S. (1997). DEA/AR efficiency and profitability of Mexican banks a total income model. European Journal of Operational Research, 98, 346-363. http://dx.doi.org/10.1016/S0377-2217(96)00352-9

The Banks Association of Turkey. (2012). Banks in Turkey. Retrieved from 
http://www.tbb.org.tr/tr/banka-ve-sektor-bilgileri/istatistiki-raporlar/--2011---bankalarimiz-kitabi---/1145

Tongzon, J. (2001). Efficiency measurement of selected Australian and other international ports using data envelopment analysis. Transportation Research Part A, 35, 107-122. http://dx.doi.org/10.1016/S0965-8564(99)00049-X

Tseng, Y. F., \& Lee, T. Z. (2009). Comparing appropriate decision support of human resource practices on organizational performance with DEA/AHP Model. Expert Systems With Applications, 36(3, Part 2), 6548-6558. http://dx.doi.org/10.1016/j.eswa.2008.07.066

Vaidya, O. S., \& Kumar, S. (2006). Analytic hierarchy process: an overview of applications. European Journal of Operational Research, 169, 1-29. http://dx.doi.org/10.1016/j.ejor.2004.04.028

Varias, A. D., \& Sofianopoulou, S. (2012). Efficiency evaluation of Greek commercial banks using DEA. Journal of Applied Operational Research, 4(4), 183-193.

Vassiloglou, M., \& Giokas, D. (1990). A study of the relative efficiency of bank branches: an application of data envelopment analysis. Operation Research Society, 41, 591-597.

Wang, Y. M., Liu, J., \& Elhag, T. M. S. (2008). An integrated AHP-DEA methodology for bridge risk assessment. Computers \& Industrial Engineering, 54, 513-525. http://dx.doi.org/10.1016/j.cie.2007.09.002

Weiguo, X., \& Ming, L. (2008). Empirical research of M\&A impact on Chinese and American commercial banks' efficiency based on DEA method. Management Science and Engineering, 2(1), 38-47.

Yuan, S., Liu, X., Tu, Y., \& Xue, D. (2008). Evaluating supplier performance using DEA and piecewise triangular fuzzy AHP. Journal of Computing and Information Science in Engineering, 8, 1-7. http://dx.doi.org/10.1115/1.2956997

Yue, P. (1992). Data envelopment analysis and commercial bank performance: a primer with applications to Missouri banks. The Federal Reserve Bank of St. LouisReview, 92(1), 31-45.

Yunten, P., \& Caner, S. (2004). Efficiency of Turkish commercial banks. Working paper, Sabanci university, Turkey. $\quad$ Retrieved from http://www.bilkent.edu.tr/ caner/file/EFFICIENCY\%20OF\%20TURKISH\%20COMMERCIAL\%20BANK S.pdf

Zhang, H., Li, X., \& Liu, W. (2006). An AHP/DEA methodology for 3PL vendor selection in 4PL. Lecture Notes in Computer Science, 3865, 646-655. http://dx.doi.org/10.1007/11686699_65 